\title{
The Implementation of Artificial Intelligence in Charity Box at Mosque and Musholla as RFID Based Security System
}

\author{
Defnizal $^{1)}$, Risa Nadia Ernes ${ }^{2)}$ \\ 1)2) Universitas Putra Indonesia "YPTK" Padang, Indonesia \\ ${ }^{1)}$ defnizal@upiyptk.ac.id , ${ }^{2}$ risanadiaernes@upiyptk.ac.id
}

Submitted : Aug 27, 2020 | Accepted : Oct 5, 2020 | Published : Oct 5, 2020

\begin{abstract}
The high crime rate in Indonesia has had a bad impact and loss on society, so that various efforts have been made to increase awareness and security in society. Charity box theft is a target of crime for criminals. For this reason, it is necessary to take strict steps in terms of vigilance and security so that the crime of theft of charity boxes can be avoided. One of the steps to increase awareness and safety is to apply the concept of security to the charity box. By utilizing several supporting sensors and supporting components in the charity box, the security system will work automatically, so that if there is a charity box theft, the system will provide an SMS notification notification to the mosque management. This research is focused on the problem of security facilities and supervision of charity boxes in mosques or mushalla. Using this system will reduce the risk of theft of charity boxes in mosques and mushalla, because apart from being equipped with an alarm and SMS gateway, this system is also equipped with RFID so that access to open charity boxes can be safer. This form of system works if the charity box is lifted or dismantled by force, the system will provide notification in the form of an alarm and SMS, so that the crime of theft of the charity box can be more aware of.
\end{abstract}

Keywords - Arduino;RFID; HC-SR05; Sensor

\section{INTRODUCTION}

Crime is a form of behavior deviation that occurs in social life, which will become a threat to the social norms of society. One of the effects of a crime or criminal act is that it can disrupt public order and social security. One type of crime that often occurs is a crime against property, namely theft of a charity box. The charity box is one of the media used to collect alms from the community. In general, the security of a charity box is very weak because it is only equipped with a padlock that is relatively easy to break into and steal. (NI Qalbi et al, 2020)

For this reason, the security of charity boxes is deemed necessary to be improved considering the high crime rate of theft of charity boxes in Indonesia, not a few parties have experienced losses caused by these criminals. Economic factors are one of the reasons for perpetrators to dare to commit crimes (Agus S, 2015).

This must be an important concern so that theft of charity boxes in mosques or musholla can be avoided. So that various efforts have been made to reduce the risk of theft of charity boxes in mosques and in musholla. One of the steps or ways that can be done is to have a security system in the charity box at the mosque or musholla. The introduction of a security system to the charity box is the first step to reduce the risk of theft of the charity box. The concept of this charity box security system is by implementing several supporting sensors, so that if there is theft of the charity box, the system will provide notification in the form of an alarm and SMS notification notification to mosque administrators. This research is focused on the problem of security facilities and supervision of charity boxes in mosques or musholla.

By using this system, it will reduce the risk of theft of charity boxes in mosques and musholla, because apart from being equipped with an alarm and SMS gateway, this system is also equipped with RFID so that access to open charity boxes can be safer. This form of system works if the charity box is lifted or dismantled by force, the system will provide notification in the form of an alarm and SMS, so that the crime of theft of the charity box can be more aware of.

\section{*Corresponding Author}




\section{Basic Concept of the System}

\section{LITERATURE REVIEW}

The system is a network of interconnected procedures and jointly carry out an activity to complete a certain goal. The system in general has the input needed to be processed and will produce output in the form of information. (Prof. Dr. Jogiyanto HM, MBA, Akt. Information Systems Structured Approach Theory and Practice of Business Applications. 2009: 1).

\section{Ultrasonic Sensor}

Ultrasonic sensors are sensors that work based on the principle of sound wave reflection and are used to detect the presence of a certain object or object in front of the working frequency in the area above the sound wave from $20 \mathrm{kHz}$ to $2 \mathrm{MHz}$ (B.Arasadaand B Suprianto, 2017). The ultrasonic sensor consists of two units, namely the transmitter and receiver units, the structure of the transmitter and receiver units. It is very simple there is a piezoelectric crystal connected to a mechanical anchor and only connected to an alternating voltage vibrating diaphragm which has a working frequency of $20 \mathrm{kHz}$ to $2 \mathrm{MHz}$ (B.Arasada and B Suprianto, 2017).

The atomic structure of a piezoelectric crystal causes it to contract to expand or shrink, a polarity of the applied voltage and this is called the piezoelectric effect in ultrasonic sensors. Ultrasonic wave reflection occurs when there is a certain object and the ultrasonic wave reflection will be received back by the receiving sensor unit. Furthermore, the receiving sensor unit will cause the vibrating diaphragm to vibrate and the piezoelectric effect produces an alternating voltage with the same frequency. To be clearer about the working principle of the ultrasonic sensor, it can be seen the principle of the ultrasonic sensor in Figure 1 below:

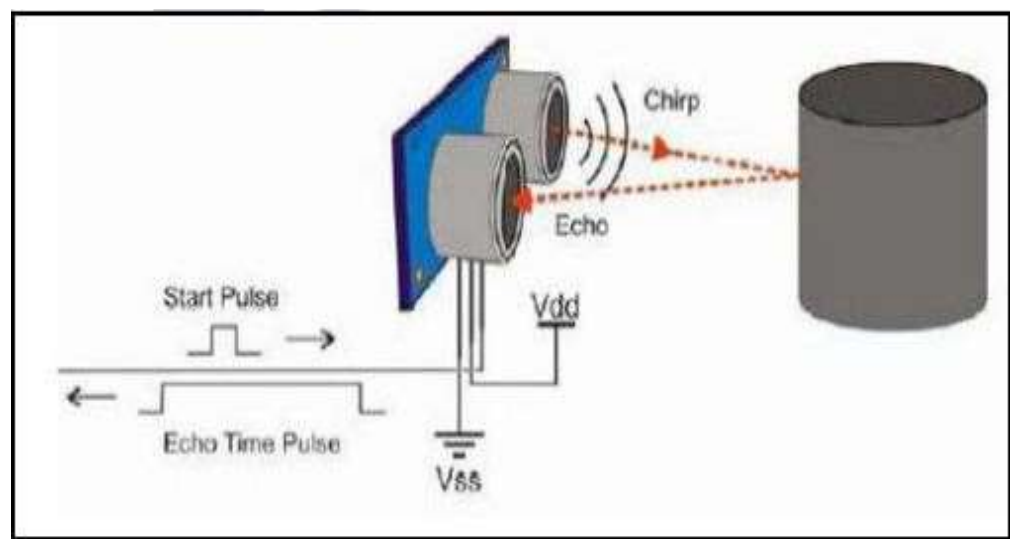

\section{SMS Gateway}

Figure 1 How The Ultrasonic Sensor Works

An SMS gateway is a device that offers SMS transit services, transforming messages to a cellular network from other media, or vice versa, thus enabling the sending or receiving of SMS messages with or without using a cell phone. (E. Permana and R. Hidayat, 2017)

An SMS Gateway system, generally consists of hardware components (server / computer equipped with network devices) and software (applications used for message processing). And for a large system generally uses a database for data storage.

\section{Arduino Uno}

Arduino Uno is a microcontroller board consisting of ATmega328. The Arduino Uno has 14 digital input / output pins (6 of which can be used as PWM outputs), 6 analog inputs, a $16 \mathrm{MHz}$ Crystal oscillator, a USB connection, a power jack, an ICSP header and a reset button. The Arduino Uno contains everything you need to support the microcontroller, it's easy to connect it to a computer with a USB cable or supply it with an AC to DC adapter or use a battery to get started. (Ruri and Surmayanti, 2016). 


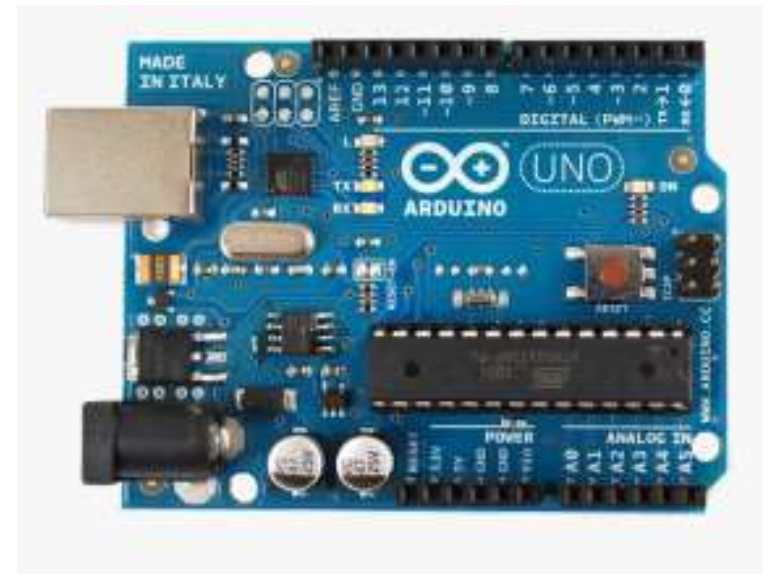

Figure 2 Arduino Uno Physical Form

\section{Radio Frequency Identification (RFID)}

Radio Frequency Identification (RFID) is a technology that utilizes radio frequency for automatic identification by utilizing a barcode or magnetic card for data retrieval. The process of identification of the RFID utilizes wave electromagnetic by because it is in the process of identification with RFID requires two devices , namely a device tag and reader. (NI Qalbi et al, 2020).

\section{METHOD}

This framework represents the steps that will be taken in order to solve the problems to be discussed, as shown in Figure 3:

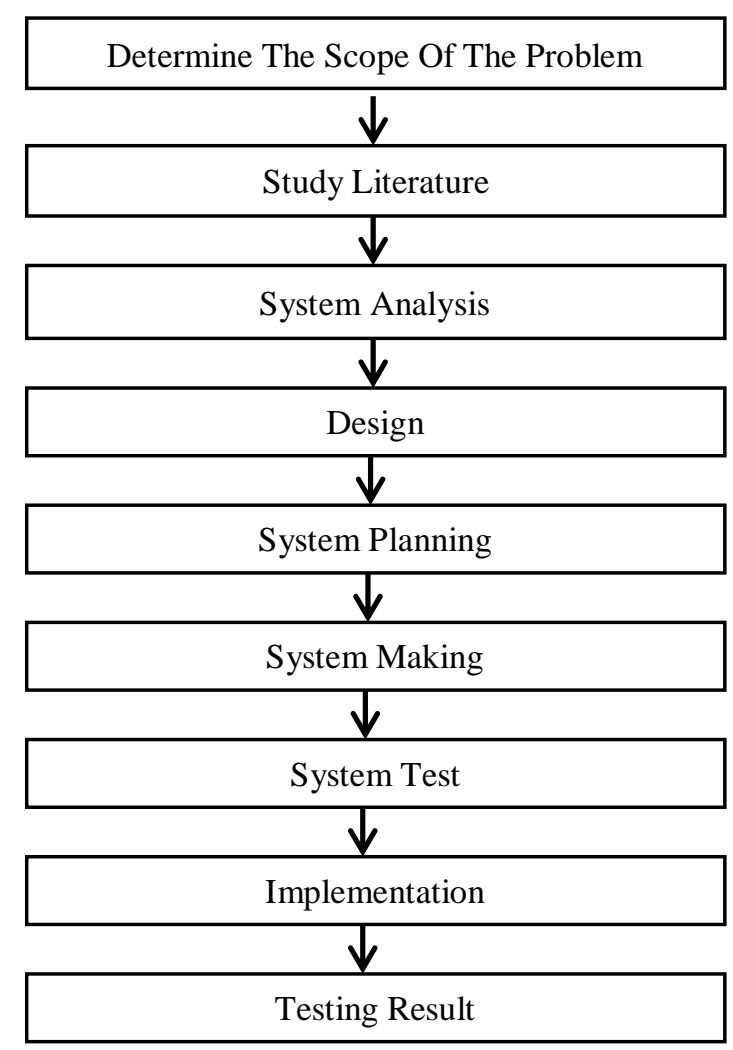

Figure 3 Research Methodology 
Based on Figure 3 above, there are steps that must be done in the research.

\section{Defining the Scope of the Problem}

The problem that will be the object of research is how to apply an artificial intelligence system to the mosque and musholla charity box so that the safety of the charity box can be increased, to avoid the risk or crime of theft of the charity box.

\section{Studying Literature}

Studying the literature aims to facilitate the research process. Then the literature studied is selected to determine which literature will be used in the study. The literature used as reference material in this research is from international scientific journals, learning modules and books on Ultrasonic Sensors, RFID, Arduino, Magnetic Door and SMS Gateway. These literatures will serve as guidelines for conducting research in order to facilitate the research process.

\section{System analysis}

The system analysis stage aims to analyze everything related to the design and manufacture of a security system for the mosque and musholla charity box. The things analyzed are as follows:

a. Use of ultrasonic and RFID sensors as input;

b. Hardware and Software used in making the system.

\section{Design}

The design stage aims to design the system to be made. Then the elements contained will be determined and these elements will be poured into the flowchart. The flow chart is a reference flow in making a security system for the mosque and musholla charity box.

\section{System planning}

The system design stage aims to design the system to be made, such as:

a. Security System Design;

b. Electronic circuit design;

c. Program design.

\section{System Creation}

At this stage, what will be made are:

a. Making Charity Box from glass and aluminum. with a size of $30 \mathrm{~cm}$ x $30 \mathrm{~cm}$;

b. Control System Creation.

\section{System Testing}

In the system testing phase, what will be tested are: The charity box security system that will be integrated with RFID, ultrasonic sensors and GSM Module and output in the form of notification in the form of sound (alarm). Arduino as software for programming with the help of a downloader tool that is used to load program files into the Arduino microcontroller. Each electronic module will be tested so that it will be known whether the module is working properly or not.

\section{Implementation}

At this stage of implementation, devices such as ultrasonic sensors and RFID will be implemented so that the system can read and process the data that will be sent to the control system and will provide information in the form of notifications in the event of theft.

\section{Testing Results}

In the results testing stage, it will be tested whether the data obtained from the input device can be processed properly so that it produces the appropriate output. What is tested at this stage are:

1. Ultrasonic Sensor;

2. RFID

3. GSM Module (Serves to provide message information) 


\section{General System Design}

\section{RESULTS}

Flow Diagram.

In general the form of the security system in this charity box candepicted using Context Diagram and Data

\section{Context Diagram}

In this study ContextThe diagram will be used to simplify the process of analyzing the system that is designed as a whole. The context diagram of the system can be seen in Figure 4.

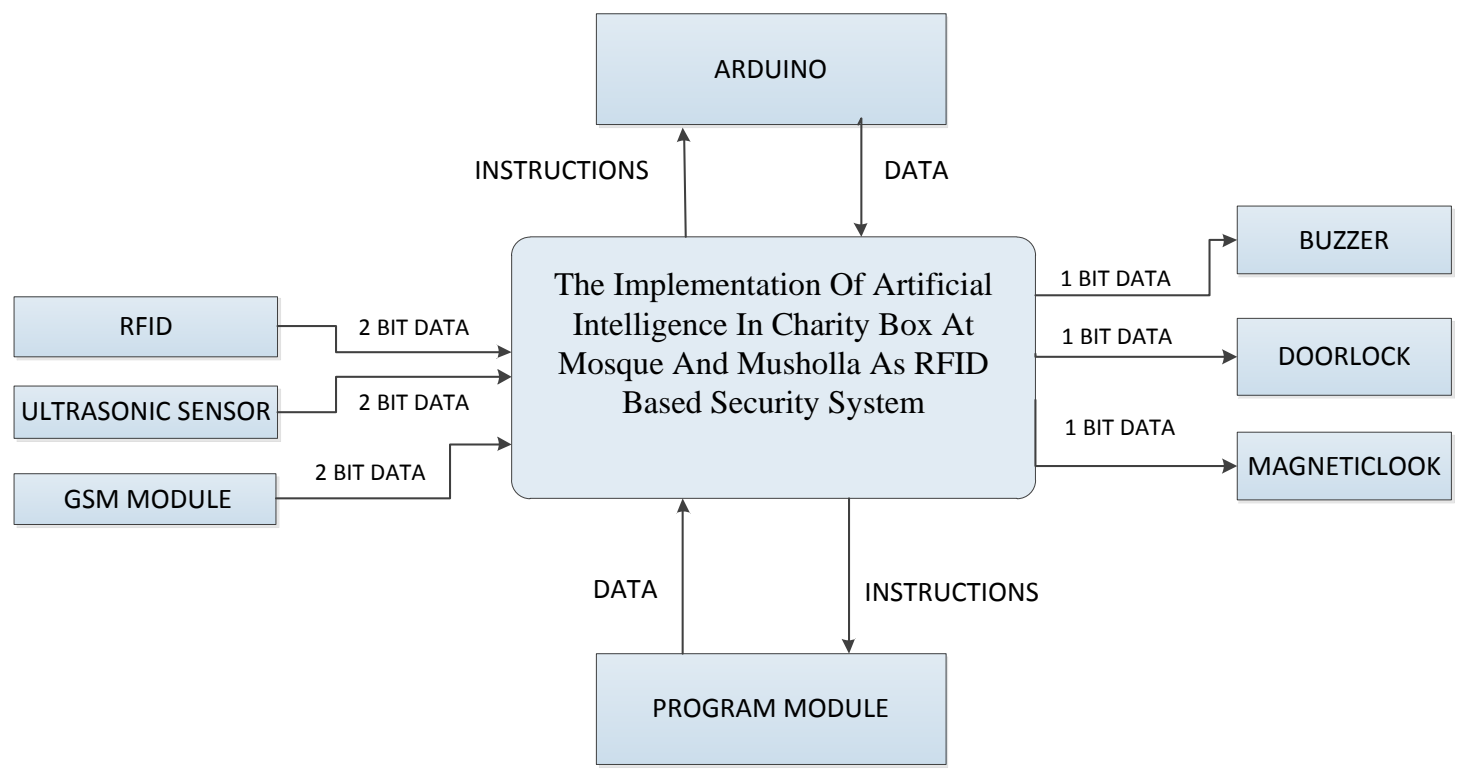

Figure 4 Context Diagram

\section{Data Flow Diagram}

Data Flow Diagramis a more detailed description of the system created. The Data Flow Diagram used is Level 0 Data Flow Diagram because only one system has been developed. Data Flow Diagram can be seen atFigure 5.

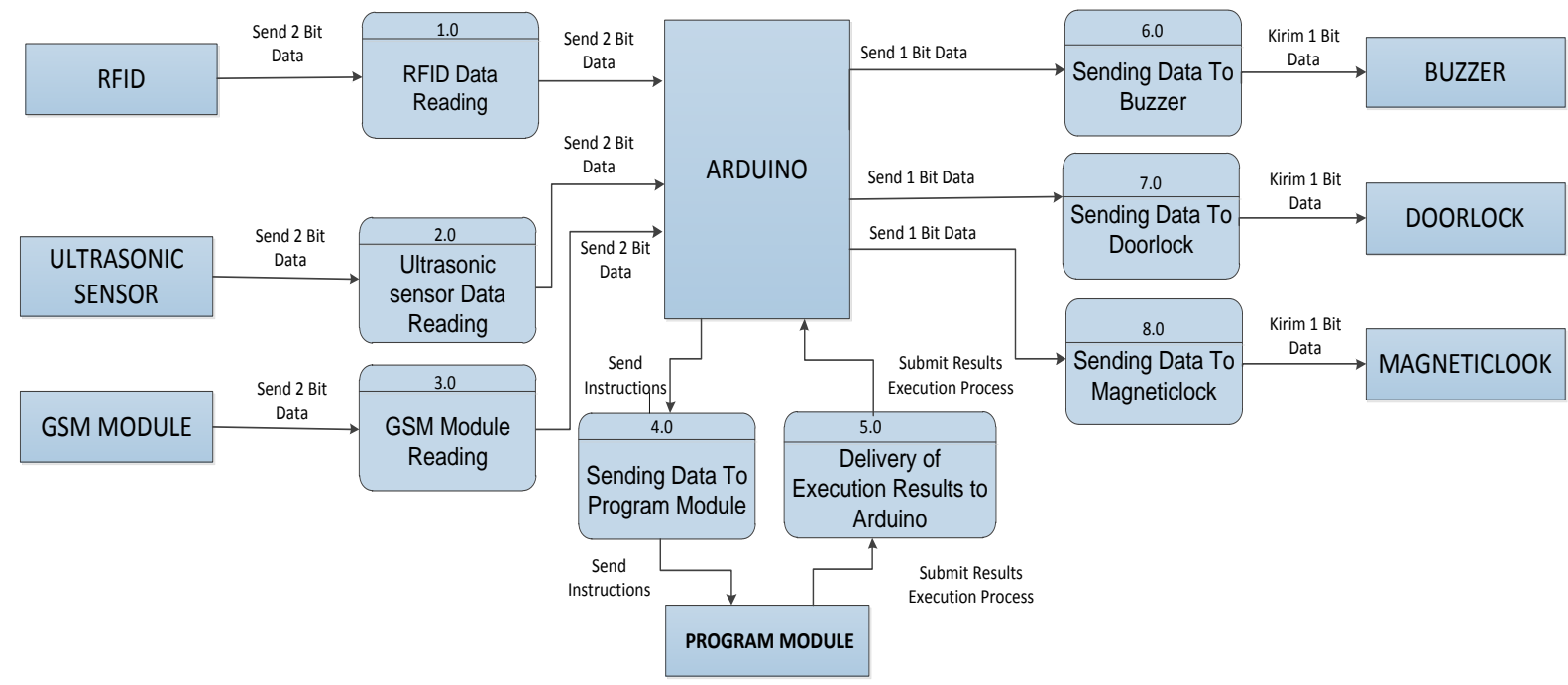

Figure 5. Data Flow Diagram 


\section{Principles of System Work}

This charity box security system will work according to instructions in the form of data input from the Ultrasonic sensor, RFID and GSM Module. The ultrasonic sensor functions to detect the distance between the charity box and the floor where the charity box is placed, while the RFID functions as a double security key to open the charity box. So when the charity box is stolen or removed deliberately beyond the safe distance or $>75 \mathrm{~cm}$, the alarm will sound for a warning and the GSM Module will send a notification in the form of a message to the mosque or musholla management that there has been theft of the charity box.

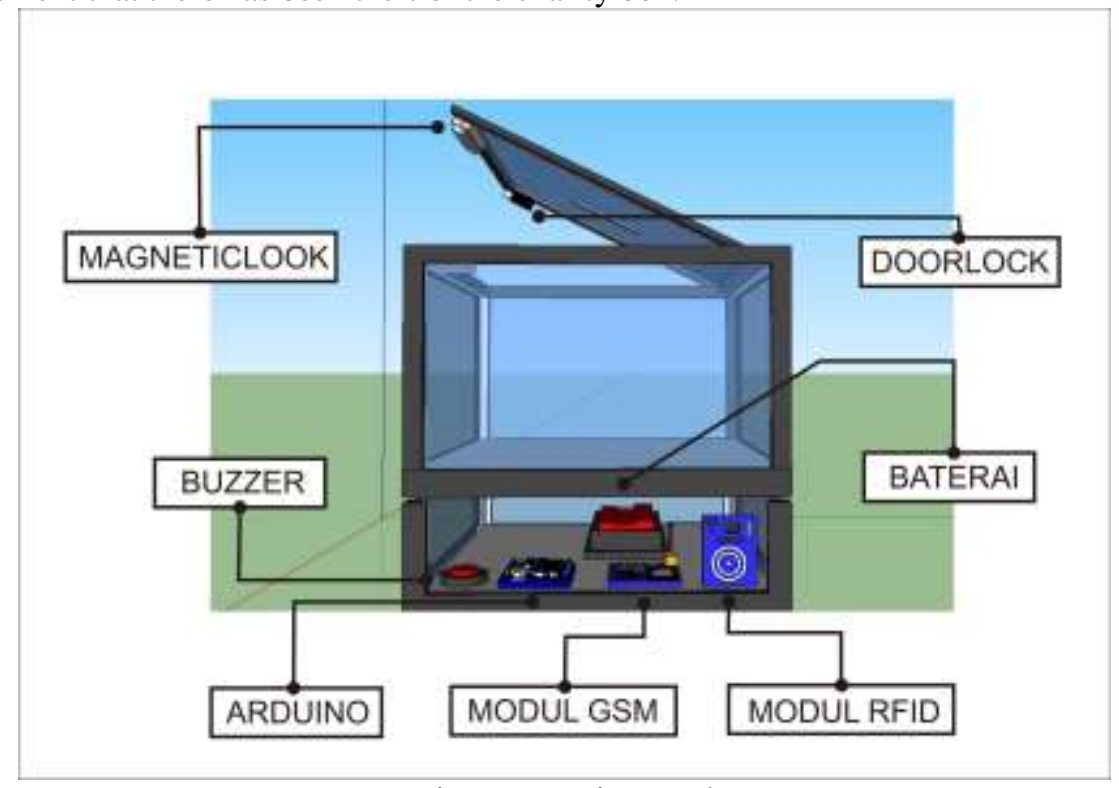

Figure 6 Design Tool

In Figure 6 above is a physical form or design tool which consists of several components, namely: Arduino which functions as a data processing center, GSM Module serves as a medium of communication that sends information in the form of SMS, RFID functions as an input medium for locking charity boxes, Battery functions as a supply of electronic circuit current voltages, Buzzer which functions as an output device in the form of an alarm, Doorlock, and Magneticlock which functions as a lock for charity boxes. With this component the system will be able to work automatically.

\section{System Testing}

\section{DISCUSSION}

The system will be active when it gets voltage from Lippo battery with a voltage of 12.4 Volt $2200 \mathrm{mAh}$. If the system has received an electric voltage / current, the sensors and components in the charity box security system will start working and will provide input.
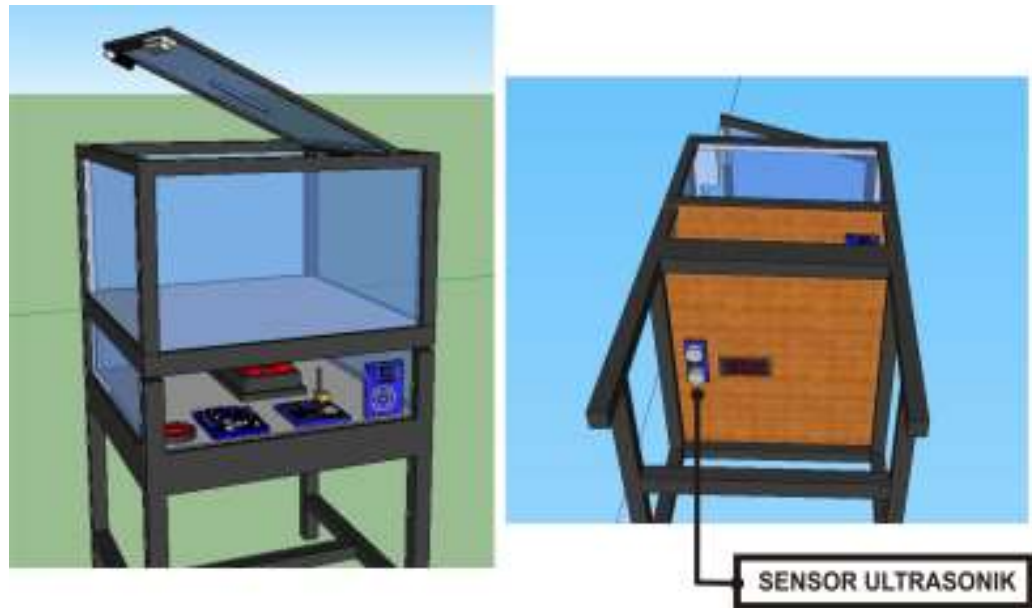

Figure 7 Display Charity Box equipped with Sensors and Electronic Components 
In Figure 7 you can see the bottom of the charity box, there is an ultrasonic sensor that functions to determine the distance of the charity box from the floor. So when the charity box is lifted, the sensor will detect the distance between the charity box and the floor.

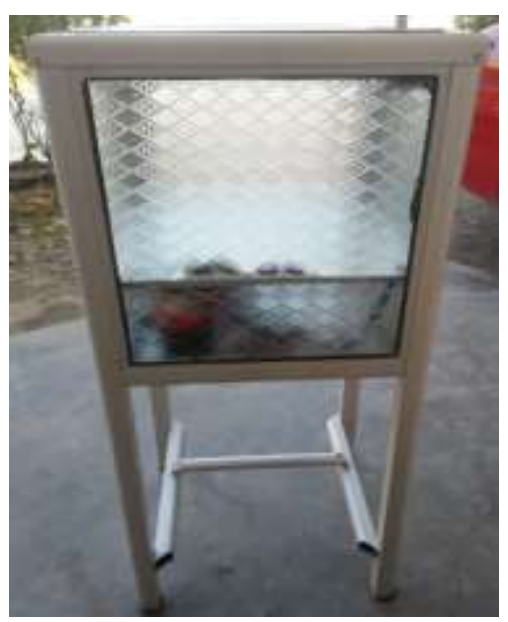

Figure 8 Physical Form of Security System for Masjid and Musholla Charity Box

Figure 8 above is a form of the security system for the charity box of the mosque and musholla, the distance of the charity box to the floor is $75 \mathrm{~cm}$. mosque automatically.

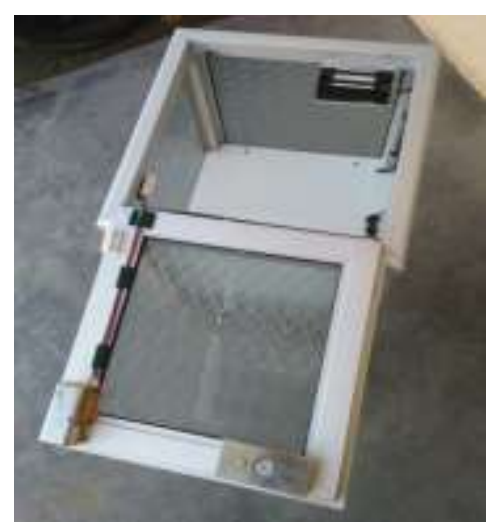

Figure 9 Use of Doorlock and Magneticlock in Charity Box Security Systems

In figure 9 seen Doorlock and Magneticlock which function to lock charity boxes automatically. So that with this doorlock and magneticklock, the charity box can be locked firmly and safely.

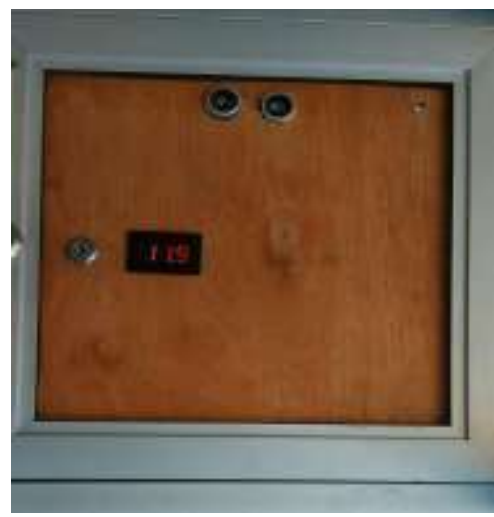

Figure 10 Display battery indicator on Charity Box Security System 
At the bottom of the charity box, besides being equipped with an ultrasonic sensor, it is also equipped with a battery indicator display, the battery indicator serves as an information medium to inform the condition of battery power.

\section{CONCLUSION}

After testing the system, it is found that all electronic components and sensors can work properly, so the system can work properly. Using the GSM Module will make it easier for administrators to get information directly about the robbery of the charity box. For the charity box locking system using RFID, so with the use of this RFID access to the charity box unlocking can be safer compared to manual keys. With the construction of this security system for the community and can reduce the risk of robbery of zakat, so that robbery of zakat boxes in mosques and musholla can be avoided.

\section{ACKNOWLEDGMENT}

Based on research conducted by many parties involved, the research team would like to thank:

a. DIPA Directorate of Research and Community Service, Directorate General of Higher Education, Directorate General of Research and Development Strengthening, Ministry of Research, Technology and Higher Education.

b. Padang Computer College Foundation and Putra Indonesia University YPTK Padang which have provided time and opportunity to conduct research.

\section{REFERENCES}

Eka Permana, RH (October 2017). DESIGN AND BUILD A HOME SECURITY SYSTEM BASED ON SMS GATEWAY USING MICROCONTROLLER. Journal of Information and Communication Technology, STMIK Subang.

Nurul Istiqamah Qalbi, et al. (April 2020). DESIGN OF INTELLIGENT CHEMICAL BOX AS A SOLUTION FOR INEFICIENCY DISTRIBUTION OF CHARACTER BOX IN MOSQUE. ELEKTRIK MEDIA Journal, Vol. 17, No. 2.

Suharsoyo, A. (March 2015). CHARACTERS OF INTERCEPTION OF THE CRIMINAL ACTION. Jurisprudence Vol. 5 No. 1.

Suprianto, BA (2017). Ultrasonic Sensor Application for Detection of Distance Position in Room Using Arduino Uno. Journal of Electrical Engineering Volume 06 Number 02, 137 - 145.

Jogiyanto, HM. 1992. The Essence of Electronics. Jakarta: PT. Elex Media Computindo

Kusumadewi, Sri (2003), "Artificial Intelligence (Technique and its application)." Yogyakarta: Graha Science.

Zain, RH \& Surmayanti, 2016. Designing an automatic water gate opening and closing system in estuaries / reservoirs using infrared sensors and photo diodes with LCD display based on Arduino Uno Atmega-328. Journal of Information Technology \& Education, 9 (1), pp. 67-72.

Andrianto, Heri. 2008. Programming of ATMEGA AVR Microcontrollers 16. Bandung: Informatics Publisher Depari, Change. 1992. Learning Theory and Electronic Skills. Bandung: PT. Elex Media Computindo

Malik, et al. 1997. Experimenting with a 8051 Microcontroller. Jakarta: PT. Gramedia.

Sutojo, T, Mulyanto, Edi, Suhartono, Vincent, Dr. (2011), "Artificial Intelligence".

Eko Harli, AF (2017). Design and Implementation of Integrated Biometric Machine SMS Gateway Technology in Academic Information Systems. Journal of Information Engineering and Educational Technology, Volume 01 Number 02 ,.

HENDI HANDIAN RACHMAT, GA (2014). Use of the RFID System as Room Access Barriers. ELKOMIKA Journal, No 1, Vol 2.

Muhammad Akil, AM (2020). THE DESIGN OF THE MESJID CHARACTER BOX WITHOUT TOUCH IN THE EFFORTS OF FACING THE NEW NORMAL ORDER IN A PLACE OF Worship MediaTIK Journal: Journal of Informatics Engineering and Computer Education Media, Vol.2 No.2.

Teguh Kurniawan, T. (2019). MANUFACTURE OF WATER FILTER AND MONITOR SYSTEM FOR ATMEGA328 MICROCONTROLLER BASED RESERVOIR. Journal of Capita Selekta Geography, 44 $55)$. 